\title{
Investigation of Meteorological Conditions Favourable for Formation of Thunderstorm Occurred Over Bangladesh Through Simulation by WRF-ARW Model
}

\author{
Dewan Abdul Quadir ${ }^{1}$, Towhida Rashid' ${ }^{2}$, Shammi Akhter² and M.N. Ahasan ${ }^{3}$ \\ ${ }^{I}$ NPI University of Bangladesh, Manikganj, Bangladesh \\ ${ }^{2}$ Department of Meteorology, University of Dhaka, Dhaka-1000, Bangladesh \\ ${ }^{3}$ Earth Science Technology and Policy Services, Dhaka-1000, Bangladesh
}

(Received : 21 July 2019 ; Accepted : 7 January 2020 )

\begin{abstract}
Investigation of meteorological conditions favorable for formation of pre-monsoon thunderstorm over Bangladesh has been conducted by simulating a selected thunderstorm case using ARW dynamic core of WRF model (WRF-ARW). A multi-cell thunderstorm formed on 30-03-2018 over the northwestern tip of Bangladesh and adjacent territories of India and moved south-southeast wards with its highest development at 09:30 UTC was selected for this study. The chosen case of thunderstorm has 3 distinct cells of which 2 cells have the width of over $100 \mathrm{~km}$ each and the third one located in the eastern Bangladesh and had the width of $50 \mathrm{~km}$. A $W R F A R W$ model has been applied to examine the atmospheic characteristics favorabe for genesis of selected case run in a double nested domain of resolution of $9 \times 9 \mathrm{~km}^{2}$ in the outer domain and $3 \times 3$ $\mathrm{km}^{2}$ in the inner domain.

The analysis of the geopotential height field of $925 \mathrm{hPa}$ level generated by WRF model at different hours of $31 \mathrm{March} 2018$ clearly indicates favourable condition with pockets of micro lows and their progression towards central to southeastern Bangladesh. The strong winds blowing from Bay of Bengal along an anticyclone over the Bay brings sufficient moisture to the north. The southerly winds meet the easterly and also westerly winds providing strong low level convergence which favors the convective activities forming cumulus cells. The orography of foothills may also enhance the convections. The wind in the upper tropospheric winds attains jet speed over these areas. The distribution of divergence and vorticity in the $925 \mathrm{hPa}$ level shows the evolution of system. The distribution of precipitation shows that the spatial patterns were well captured. Vertical velocity has been plotted along the vertical-horizontal plane oriented in the east-west direction across a high rainfall cell. This shows that the highest development of narrow vertical cell extends up to $100 \mathrm{hPa}$ level. Following the temporal evolution of the system, it is seen that the highest development delayed by around 2 hours. Some mitigation strategies in respect of thunderstorms and associated lighting are also discussed.
\end{abstract}

Keywords: WRF Model, FNL, Thunderstorm, Meteorological Condition, Simulation

\section{Introduction}

Bangladesh, a small country over the eastern portion of South Asia extended over the latitudes of $20^{\circ} 34^{\prime}-26^{\circ} 38^{\prime} \mathrm{N}$ and longitudes of $88^{\circ} 01^{\prime}-92^{\circ} 41^{\prime} \mathrm{E}$, is frequently visited by thunderstorms in pre-monsoon season. Thunderstorms accompany with stormy winds, torrential rains and hails. Sometimes they become highly destructive with tornadic strength. Thunderstorms of Bangladesh originate either within the territories of Bangladesh or they get regenerated from those propagated from northwest after being developed over territories of India lying adjacnt to northwest and northern Bangladesh ${ }^{1}$. As most of the storms comes from northwest these stroms are often referred to as Nor'westers and are narrated as "Kalbaishakhi" as well in Bangla meaning destruction of the month of Baisakh coinciding with 14 April-14 May.

Thunderstorms develop due to intense atmospheric convection caused by high instability. The instability is associated with the flow of moistened warm air approaching inland of Bangladesh from the Bay of Bengal $(\mathrm{BoB})$ with cold westerly flow in the higher levels. Besides, the negative anomaly of surface and low-level pressure fields also provides advantageous circumstances for the genesis of thunderstorm ${ }^{2}$.
The horizontal scale of thunderstorms varies from 10-300 kilometer whereas the typical life span is less than an hour, but multi-cell systems resulted from intense convections show a different characteristics which can last for a few hours, and advance through a space of few hundres of kilometers. These storms are often very stormy and generally have wind speed of $60-150 \mathrm{~km} / \mathrm{h}$ with exceptions of tornadoes having wind speed of $250 \mathrm{~km} / \mathrm{h}$ or more. Climatology of thunderstorms of Bangladesh along with some atmospheric conditions conducive to their formation have been described by Saha and Quadir $(2016)^{2}$ and Karmakar $(2001)^{3}$ and Das (2010) ${ }^{4}$.

An event of multi-cell thunderstorm formed on 30-03-2018 over the northwestern tip of Bangladesh and adjacent territories of India and moved south-southeast wards with its highest development at 9:30 GMT (15:30 BST). According to cloud imagery of INSAT 3D satellites, it is found that the formation of the thunderstorm began at 2300 UTC of 29 March 2018 with three small bubbles of cumulus clouds over the Indian territories adjacent to northwestern tip of Bangladesh, which passed through remarkable development with the progress of time and moved towards the southeast direction. At 1000 UTC, the system in its mature stage had three distinct cells of which two cells had the width of over $100 \mathrm{~km}$ each and the third

*Author for correspondence. e-mail: dmnamet@gmail.com 
one located in the eastern Bangladesh and had the width of about $50 \mathrm{~km}$. The IR cloud images at (a) 0900 UTC, (b) 1000 UTC and (c) 1100 UTC by INSAT satellite on 30 March 2018 demonostrate this sequencial development [Fig.1.(a-c)].

Table 1. Accumulated rainfall of one day ( 24 hour) along with wind type, wind speed and wind direction recorded at various stations of Bangladesh Meteorological Department (BMD) on 30 March 2018.

\begin{tabular}{|c|c|c|c|c|c|}
\hline $\begin{array}{l}\text { Sta- } \\
\text { tion }\end{array}$ & $\begin{array}{l}\text { Type of } \\
\text { system }\end{array}$ & $\begin{array}{l}\text { Wind } \\
\text { speed } \\
(\mathbf{k m} / \mathbf{h})\end{array}$ & $\begin{array}{l}\text { Wind } \\
\text { direc- } \\
\text { tion }\end{array}$ & Ti-me & $\begin{array}{l}\text { Rainfall } \\
\text { (mm) }\end{array}$ \\
\hline Syl-het & Squall & 78 & W'ly & $\begin{array}{l}\text { 0950- } \\
1020 \\
\text { UTC }\end{array}$ & 23 \\
\hline $\begin{array}{l}\text { My- } \\
\text { men- } \\
\text { singh }\end{array}$ & Squall & 59 & NW'ly & $\begin{array}{l}0950- \\
1020 \\
\text { UTC }\end{array}$ & \multirow[t]{2}{*}{10} \\
\hline $\begin{array}{l}\text { Mymen- } \\
\text { singh }\end{array}$ & Squall & 59 & E'ly & $\begin{array}{l}2230- \\
2300 \\
\text { UTC }\end{array}$ & \\
\hline $\begin{array}{l}\text { PBO } \\
\text { Dha-ka }\end{array}$ & $\begin{array}{l}\text { Gusty } \\
\text { wind }\end{array}$ & 44 & & $\begin{array}{l}1038 \\
\text { UTC }\end{array}$ & \multirow[t]{3}{*}{1} \\
\hline $\begin{array}{l}\text { PBO } \\
\text { Dha-ka }\end{array}$ & $\begin{array}{l}\text { Gusty } \\
\text { wind }\end{array}$ & 67 & NE'ly & $\begin{array}{l}1057 \\
\text { UTC }\end{array}$ & \\
\hline $\begin{array}{l}\text { PBO } \\
\text { Dha-ka }\end{array}$ & $\begin{array}{l}\text { Gusty } \\
\text { wind }\end{array}$ & 48 & N'ly & $\begin{array}{l}1104 \\
\text { UTC }\end{array}$ & \\
\hline $\begin{array}{l}\text { Farid- } \\
\text { pur }\end{array}$ & Squall & 46 & NW'ly & $\begin{array}{l}0950- \\
1020 \\
\text { UTC }\end{array}$ & 0 \\
\hline
\end{tabular}

The thunderstorm of 30 March 2018 was an unique case which had three clear cells and demonstrated gradual development as it moved to southeast and was associated with strong wind and strong showers of hails which became the causes of huge damages of lives, houses with CI sheet roofs, crops and trees. The meteorological conditions favourable for formation of this thunderstorm has been investigated using ARW dynamic solver of WRF (WRFARW) model with non-hydroscopic form of the momentum equations.

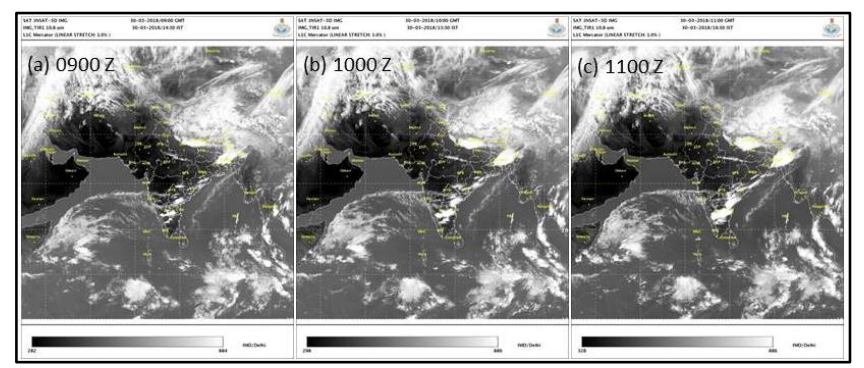

Fig.1. IR cloud images at (a) 0900 UTC, (b) 1000 UTC and (c)

1100 UTC on 30 March 2018 by INSAT satellite.

\section{Elucidation of the Model}

A new generation meso-scale non-hydrostatic model namely Weather Research and Forecast (WRF) model based on numerical weather prediction techniques meets the needs of both atmospheric research and forecasting weather. It contains two dynamic solvers: one (ARW solver) is founded by National Center for Atmospheric Research (NCAR) and the other (Non-hydrostatic Mesoscale Model (NMM) solver) which is established primarily by National Centers for Environmental Prediction (NCEP). The present simulation has been executed on the basis of ARW solver which is formulated following a Eulerian approach (the approach in which coordinate system is fixed but the control volume is moving and by this way carrying the mass). Parallel computing is also enabled here ${ }^{13}$. WRF model shows satisfactory progress in data assimilation, physics parameterization researches, executing air quality models as well as climate downscaling, atmosphere-ocean coupling, and idealized simulations. This model can operate on simulation of meteorological phenomena that spans over meters to thousands of kilometers.

The dynamic solver of WRF model that means ARW solver is based on the time integration technique of third order Runge-Kutta method. In the model the integration is performed on some Euler equations of nonhydrostatic nature (which means the opposite of static atmosphere). All variables of the equations follow the conservation laws of mass, momentum and energy.

In our present study, model has 38 numbers of vertical layer incorporated in it.

The flux form of the prognostic (for prediction purpose) Eulerian equation can be expressed as

$$
\begin{aligned}
& \partial_{t} U+(\nabla \cdot V u)-\partial_{x}\left(p \phi_{n}\right)+\partial_{\eta}\left(p \phi_{x}\right)=F_{U} \\
& \partial_{t} V+(\nabla \cdot V v)-\partial_{y}\left(p \phi_{n}\right)+\partial_{\eta}\left(p \phi_{y}\right)=F_{V} \\
& \partial_{t} W+(\nabla \cdot V w)-g\left(\partial_{\eta} p-\mu\right)=F_{W} \\
& \partial_{t} \Theta+(\nabla \cdot V \Theta)=F_{\Theta} \\
& \partial_{t} \mu+(\nabla \cdot V)=0 \\
& \partial_{t} \phi+\frac{1}{\mu}(V \cdot \nabla \phi)-g W=0
\end{aligned}
$$

And the diagnostic (to characteristic analysis purpose) equation is of the form

$\partial_{\eta} \phi=-\alpha \mu(7)$

With the equation of state in the atmosphere being

$p=p_{0}\left(R_{d} \frac{\theta}{p_{0}} \alpha\right)^{\gamma}$

Here $\theta, \varphi(=g z), p \quad$ and $\quad \alpha\left(=\rho^{-1}\right)$ represent potential temperature, geopotential, pressure and inverse density respectively and $F_{U}, F_{V}, F_{W}$ and $F_{\Theta}$ on the right hand sides are forcing terms due to model physics, turbulent mixing due to friction at planetary boundary layer, projections in the sphere, and rotation due to the motion of the earth. $\gamma=\frac{C_{p}}{C_{v}}$ is the ratio of the heat capacities with the value of 1.4 for dry air, $R_{d}$ is the gas constant for dry air and $p_{0}$ presents a reference pressure with a typical value being $1000 \mathrm{hPa}$. 
$\boldsymbol{V}=\mu \boldsymbol{v}=(U, V, W)$

$\operatorname{And} \Theta=\mu \theta$

$\boldsymbol{v}=(u, v, w)$ represents the covariant velocities in the two horizontal $(x, y)$ and vertical $(z)$ directions respectively. $\mu(x . y)$ is the mass per unit area at specific point $(x . y)$ of the domain in the model ${ }^{12}$.

\section{Exploratory Arrangement of Model}

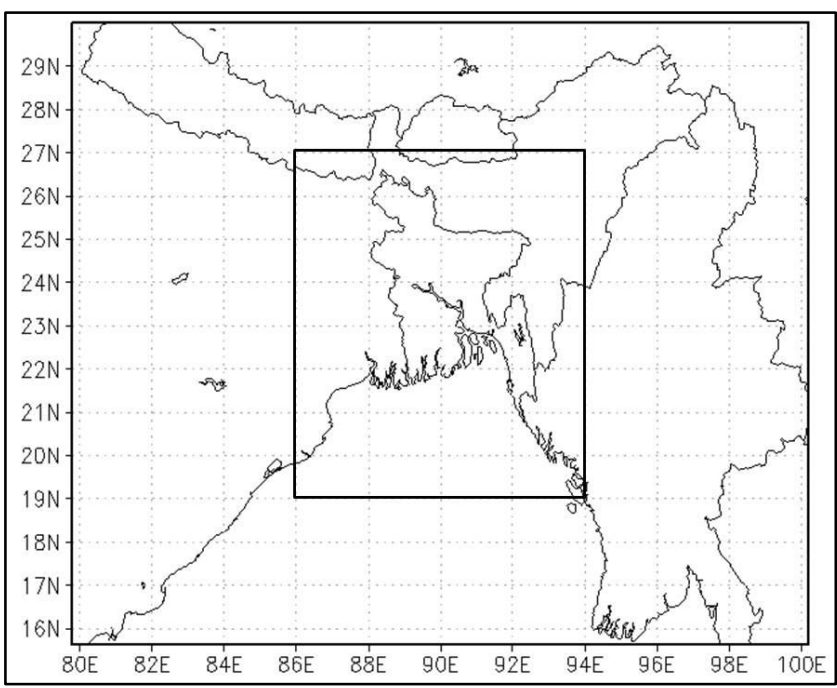

Fig. 2. Domain defined for NWP study on 30 March 2018.

A double nested model domain constructed over the map with topographical framework of that region is represented in Fig 2. The area of the parent domain incorporated in the model for the present research is $124 \times 103 \mathrm{~km}^{2}$ centered at $23^{\circ} \mathrm{N}, 90^{\circ} \mathrm{E}$ (near Gopalganj). Double nested domain has a horizontal grid resolution of $9 \times 9 \mathrm{~km}^{2}$ for parent domain and $3 \times 3 \mathrm{~km}^{2}$ for child domain. By this nesting domain, it will be possible to investigate detail features of circulation and flow of winds over the areas in and around the selected thunderstorms. Different parameterization schemes are formulated in this model in order to explain physics and dynamics of a weather system. Table 2. shows names of the particular schemes that have been used in the present work. The model is run on thirty-eight number of vertical level where pressure is taken as vertical coordinate in our system of coordinates.

Table 2. The table showing the parameterization schemes for describing physics and dynamics aspects of the processes.

\begin{tabular}{|l|l|l|}
\hline \multirow{5}{*}{ Physics } & Cumulus & $\begin{array}{l}\text { Kain-Fritsch (new } \\
\text { Eta) scheme }\end{array}$ \\
\cline { 2 - 3 } & $\begin{array}{l}\text { Microphysics of } \\
\text { cloud }\end{array}$ & $\begin{array}{l}\text { WSM 6 class } \\
\text { graupel schemes }\end{array}$ \\
\cline { 2 - 3 } & Radiation & $\begin{array}{l}\text { Rapid Radiative } \\
\text { Transfer Model } \\
\text { (RRTM) scheme } \\
\text { (for longwave } \\
\text { solar radiation) }\end{array}$ \\
\cline { 3 - 3 } & Dudhia scheme \\
\hline
\end{tabular}

\begin{tabular}{|l|l|l|}
\hline \multirow{5}{*}{ Dynamics } & $\begin{array}{l}\text { (for shortwave } \\
\text { terrestrial } \\
\text { radiation }^{16}\end{array}$ \\
\hline \multirow{5}{*}{} & $\begin{array}{l}\text { Planetary Boundary } \\
\text { Layer }\end{array}$ & $\begin{array}{l}\text { Yonsei University } \\
\text { (YSU) scheme) }^{17}\end{array}$ \\
\hline & $\begin{array}{l}\text { Time Integration } \\
\text { Technique }\end{array}$ & $\begin{array}{l}\text { Runge-Kutta third } \\
\text { order method }\end{array}$ \\
\cline { 2 - 3 } & $\begin{array}{l}\text { Vertical } \\
\text { Differencing }\end{array}$ & $\begin{array}{l}\text { Arakawa's } \\
\text { Energy } \\
\text { Conserving } \\
\text { Scheme }\end{array}$ \\
\cline { 2 - 3 } & Spatial differencing & $\begin{array}{l}\text { Sixth order } \\
\text { centered } \\
\text { difference scheme }\end{array}$ \\
\cline { 2 - 3 } & Robert's Method \\
\cline { 2 - 3 } & Time percolation & Arakawa C-grid \\
\cline { 2 - 3 } & Horizontal grid &
\end{tabular}

While simulating by the model the starting time was (initial boundary condition) 0000 UTC of 30 March 2018 and the model was run over a 24 hours period (lateral boundary condition).

\section{Origin of Data}

For initial and lateral boundary condition, Global Final (FNL) reanalysis data having $1^{\circ} \times 1^{\circ}$ horizontal resolution and temporal coverage of 6 hours provided by NCEP was employed as input data for simulation. Datasets having 30 second horizontal resolution contributed by United States Geological Survey (USGS) serves for the topography, land cover, terrain and vegetation purposes.

To find out the contrast between observed data and simulated rainfall and to proclaim the capacity of the model to simulate atmospheric phenomena, the daily rainfall data recorded at different observatory of BMD was collected from the archive of that organization. Rainfall data captured by the satellite of Tropical Rainfall Measuring Mission (TRMM) project and cloud cover images reproduced by INSAT satellite were also utilized for the authentication motive.

\section{Strategy and Procedures of Research}

The NOAA NCEP FNL datasets of 30 March 2018 was used for initialization of the model and feeding updated data in the lateral boundary. The start time for the simulation was 0000 UTC of 30 March and the end time was 0000 UTC of 31 March i.e., the model was run over a time period of 24 hour.Grid Analysis and Display System (GrADS) software was used for analyzing and visualizing the results. Parameters such as sea level pressure, geopotential height, lower and upper tropospheric wind flow, low level relative vorticity, Outgoing Longwave Radiation (OLR), distribution of moisture flux (both horizontally and vertically), vertical wind shear of the zonal component of the wind in the lower troposphere and rainfall. Instability indices like Convective Available Potential Energy (CAPE) and Convective Inhibition Energy (CINE) were visualized on hourly basis.The plotted maps were interpreted to explain the meteorological conditions 
favorable for the development and evolution of the thunderstorm event. While examining, particular attention was provided for the time 1000 UTC when the thunderstorm was in its fully developed stage positioned in the east to west central part of the country. The system situated in the northernmost part of our country at about 0930 UTC (detected by INSAT satellite). Total precipitation contributed by convective (attributed by Cumulus scheme) and non-convective (attributed by Grid Scale) mechanism at surface level has been estimated and taken for the analysis of rainfall. The model simulated rainfall has been anticipated with both the daily observed rainfall data recorded by BMD and TRMM estimated rainfall data according to both space and time.

\section{Results and Discussions}

The results found upon simulating and analyzing the model output can be documented in the following manner:

\section{Mean Sea Level Pressure}

Emergence of a low pressure area is the prerequisite for initiating convective activities which leads to the origination of a thunderstorm. Geographical distribution of WRF simulated mean sea level pressure (valid for 1000 UTC) shows that a trough of low pressure extends along the Gangetic plain of India to Bangladesh, while the core of lowest pressure of $1004 \mathrm{hPa}$ is situated over Uttar Pradesh in India (Fig.3.). The low pressure advances to the east and intensifies with the progress of time. This situation anticipates the genesis and progress of a thunderstorm over Bangladesh.

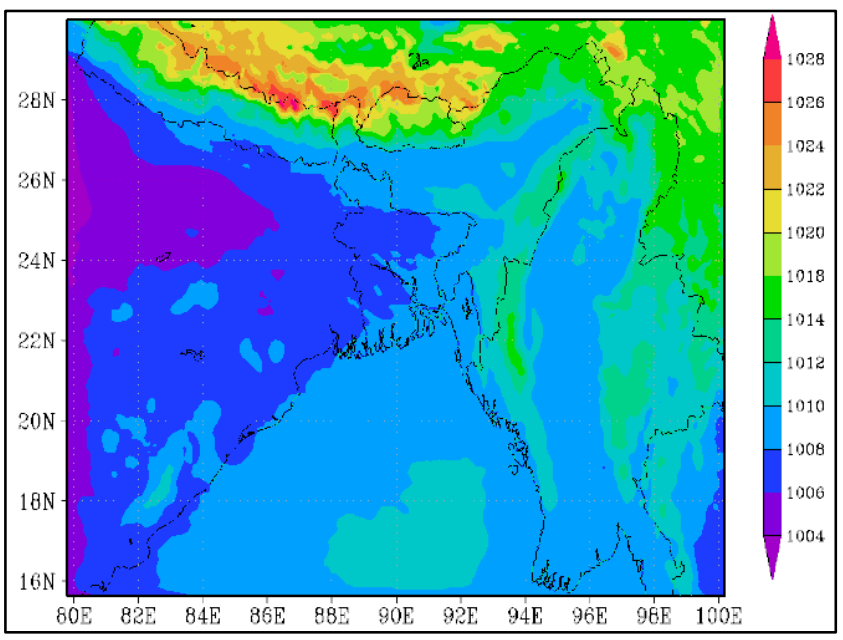

Fig. 3. Mean sea level pressure (unit: hPa) at 1000 UTC on 30 March 2018.

Geopotential Height at $950 \mathrm{hPa}$ (Low) and $250 \mathrm{hPa}$ (High) Level

The analysis of the spatial distribution of geopotential height $(\mathrm{m})$ at lower troposphere $(950 \mathrm{hPa}$ level) and upper troposphere (250 hPa level) is shown in Fig.4. (a, b). It is well established that low values of geopotential correspond to low pressure and high values indicates high pressure over an area. It is seen that the low pressure trough extends over the northern part of Bangladesh and adjacent territories of India and maintains a pressure gradient from west to east with its axis slightly tilted towards south. The thunderstorm under study was found to occur in the eastern tip of this low pressure trough, which manifests the one of the most important conditions for the genesis of thunderstorms. The distribution of heights at $250 \mathrm{hPa}$ level indicates extension of a trough over the areas with low geopotential height over the northern Bangladesh and adjacent Indian territories which is a manifestation of required upper air circulation favorable for thunderstorm formation.

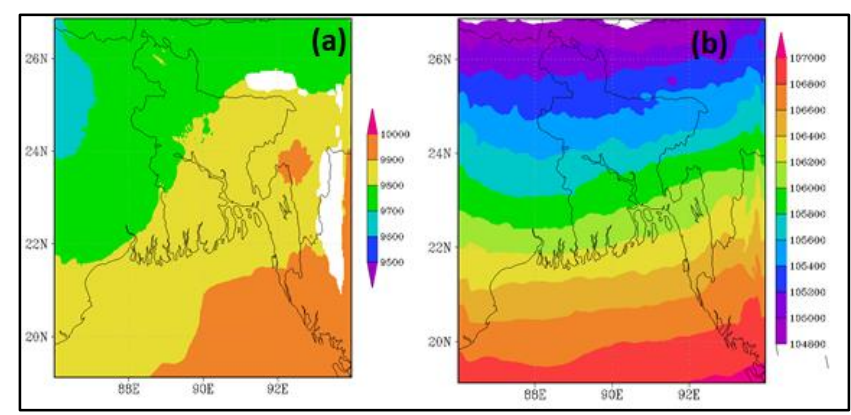

Fig. 4. Geopotential Height at $950 \mathrm{hPa}$ (a) and $250 \mathrm{hPa}$, (b) at 1000 UTC on 30 March 2018.

Lower tropospheric (950hPa) wind

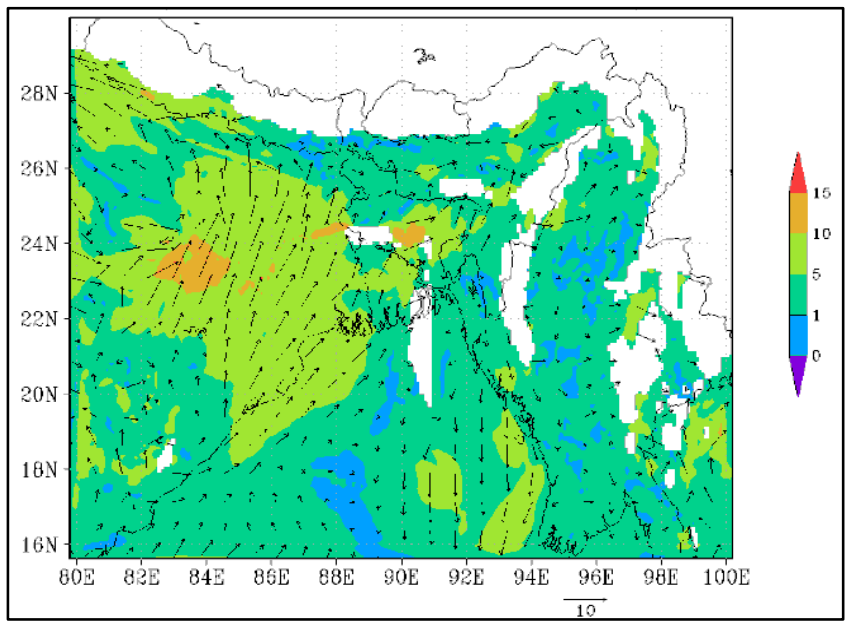

Fig. 5. Depiction of $950 \mathrm{hPa}$ (low) level wind flow (unit $\mathrm{ms}^{-1}$ ) at 1000 UTC of 30 March 2018.

Fig. 5. presents the depiction of the lower tropospheric ( 925 $\mathrm{hPa}$ ) wind flow (unit: $\mathrm{ms}^{-1}$ ) of 30 March 2018 at 1000 UTC. It is evident that, the wind blows from the Bay of Bengal into the mainland of Bangladesh. The air blowing from the sea is very moist and then eventually this vigorous southwesterly flow carries huge amount of moisture inlands over Bangladesh, which converge with relatively cold and dry winds in the base of sub-Himalayan hills. A strong low level stream with wind speed of the order of $10-15 \mathrm{~ms}^{-}$ ${ }^{1}$ isobserved over the central and northeast portion of Bangladesh and over the areas in and to the west of west Bengal which constitute a cyclonic circulation. The moist air from the sea converged over these areas. The wind from 
the sea piles up extensive amount of moisture. As the area is situated within a strong east-west oriented low pressure trough in the lower atmosphere and another low pressure trough extends to the south over this area at $250 \mathrm{hPa}$, which provides favorable conditions for the highly moist air parcels to be uplifted with strong buoyancy force resulting to the birth of cumulonimbus clouds. The dry line can be detected undoubtedly over the northern part of the country where warm moist air coming form Bay of Bengal encounter cold dry air blowing from the Sub-Himalayan Range.

\section{Upper tropospheric (300 hPa) Winds}

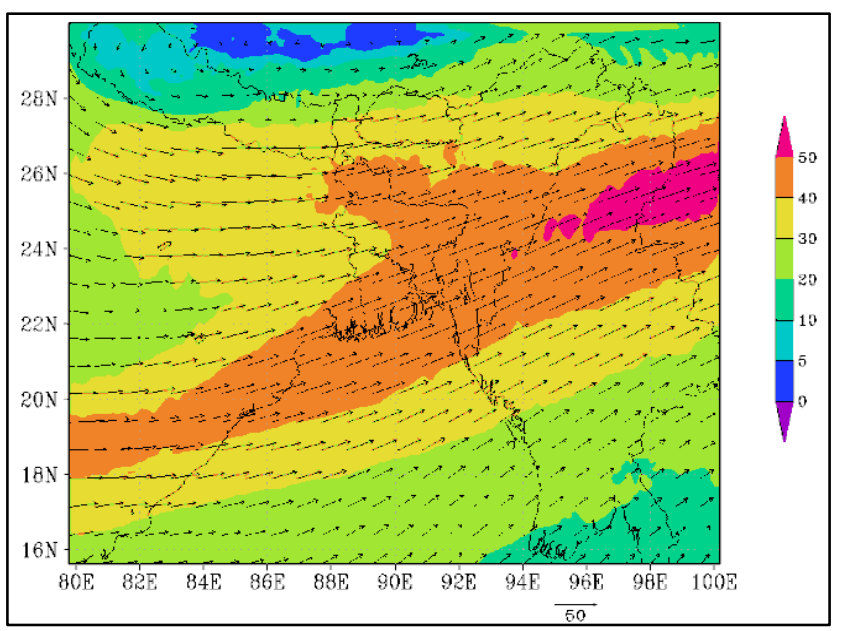

Fig. 6. Depiction of $300 \mathrm{hPa}$ (upper) level wind flow (unit in $\mathrm{ms}^{-1}$ ) at 1000 UTC of 30 March 2018.

The depiction of the upper tropospheric $(300 \mathrm{hPa})$ wind flow (unit in $\mathrm{ms}^{-1}$ ) of 30 March 2018 at 1000 UTC have been exhibited in Fig.6. The subtropical jet stream with wind speed of the order of $40-50 \mathrm{~ms}^{-1}$ is clearly visible over the areas of thunderstorm development. Over the most part of the Bangladesh, the wind speed is over $40 \mathrm{~ms}^{-1}$ at 300 $\mathrm{hPa}$ level. The vector wind exhibits the existence of troughs over the northern Bangladesh exhibiting cyclonic circulation also in the upper troposphere. Comparing the wind distribution of the upper and lower troposphere, it is seen that there exists robust vertical wind shear between the 950 and $300 \mathrm{hPa}$ layers over north part of Bangladesh and adjacent areas.This intense vertical wind shear aids in vigorous convection, which might lead to the rapid growth of thunderstorm.

\section{Vertical wind shear of Zonal Wind Component}

Vertical wind shear (unit: $\mathrm{ms}^{-1}$ ) of zonal component of the wind between 500 and $950 \mathrm{hPa}$ level in the atmosphere on 1000 UTC of 30 March 2018 is depicted in Fig.7. High vertical wind shear $\left(\sim 20-25 \mathrm{~ms}^{-1}\right)$ is notable over the central Bangladesh and the core region elongated up to some parts of Bihar and West Bengal. This inflated vertical extent of wind shear might favor the growth of towering cumulonimbus clouds, which ultimately leads to multi-cell thunderstorms) $)^{18}$.

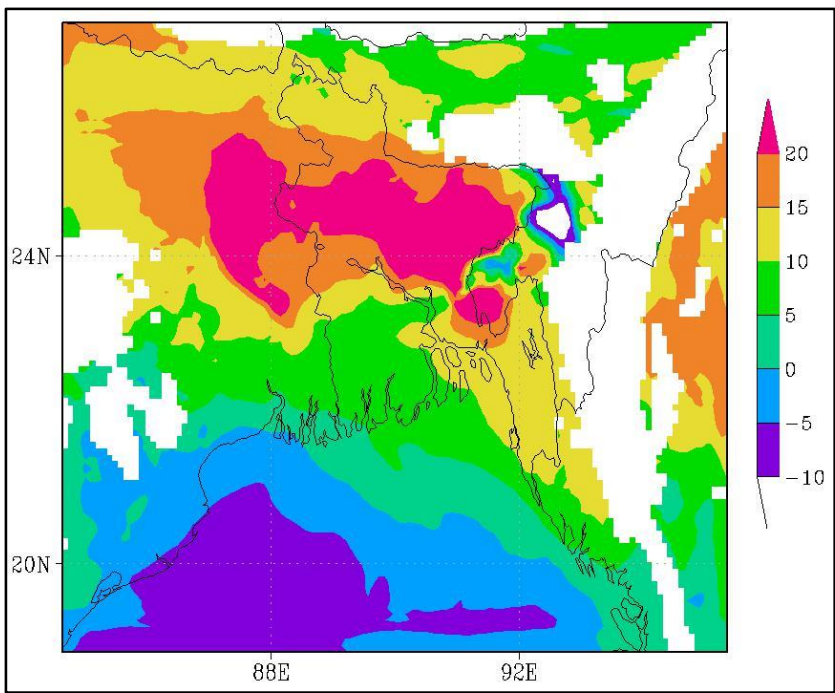

Fig. 7. Vertical wind shear (unit in $\mathrm{ms}^{-1}$ ) of zonal wind component between 500 and $950 \mathrm{hPa}$ level at 1000 UTC on 30 March 2018.

\section{Moisture distribution}

Fig. 8. (a) shows how atmospheric moisture in term of relative humidity $(\mathrm{RH} \%)$ is distributed in the lower troposphere at $950 \mathrm{hPa}$ level on 1000 UTC of 30 March 2018. Central and northern part of Bangladesh exhibits high concentration of moisture, while the surrounding areas to the west, east and south are found to be very dry. In the vertical section along $24.3 \mathrm{~N}$ passing through Mymensingh and Sylhet, it is found that high relative humidity (> 80\%) is confined mainly in the boundary layer and slightly above up to $800 \mathrm{hPa}$ (Fig.8. (b)). It decreases fast in the vertical, in $400-500 \mathrm{hPa}$ levels it is found that the $\mathrm{RH} \%$ values reach up to $50 \%$. Both spatial and vertical distributions indicate the existence of high instability with light moist air in the lower troposphere and heavy dry air in the middle and upper troposphere. This condition favors the initiation of strong convection leading to the formation of thunderstorms.

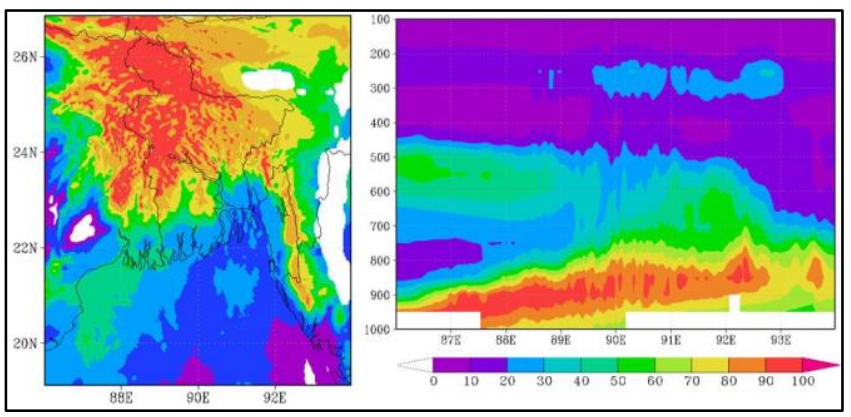

Fig. 8. Relative humidity (RH \%) (horizontal) (a) and Vertical extension of RH\% across $24.30^{\circ} \mathrm{N}$ latitude (b) at 1000 UTC of 30 March 2018

\section{Relative Vorticity at Lower Troposphere}

Fig.9. represents the horizontal distribution of relative vorticity (unit: $\mathrm{s}^{-1}$ ) at $950 \mathrm{hPa}$ (lower troposphere) level at 1000 UTC of 30 March 2018. The extremities of the values 
of vorticity are arranged in parallel rows with low values of vorticities in-between signifies the manifestation of the complicated structures of the thunderstorms. The values of vorticity over these regions ranges from 0.00001 to 0.00002 $\mathrm{s}^{-1}$. High positive values of vorticity at the lower troposphere indicate the outset of vigorous convective activities over the respective areas.Very interesting feature is demonstrated by the vorticity fields, which are arranged in northwest to southeast oriented stripes with alternating positive and negative vorticity signifying ascending and descending motion within the convective cells.

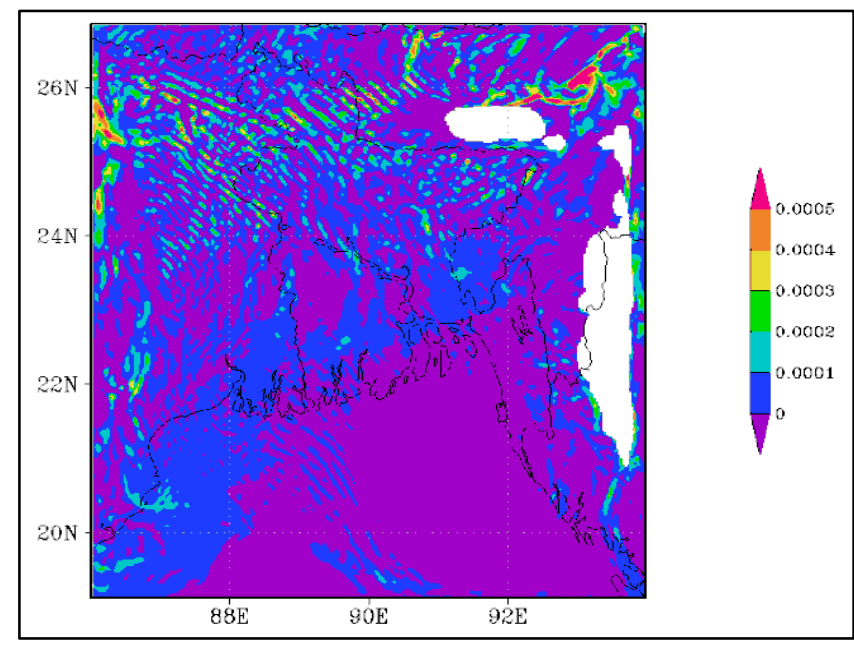

Fig. 9. Relative vorticity at lower level of troposphere $(925 \mathrm{hPa})$ (unit: $\mathrm{s}^{-1}$ ) on 1000 UTC of 30 March 2018.

\section{Outgoing Longwave Radiation (OLR)}

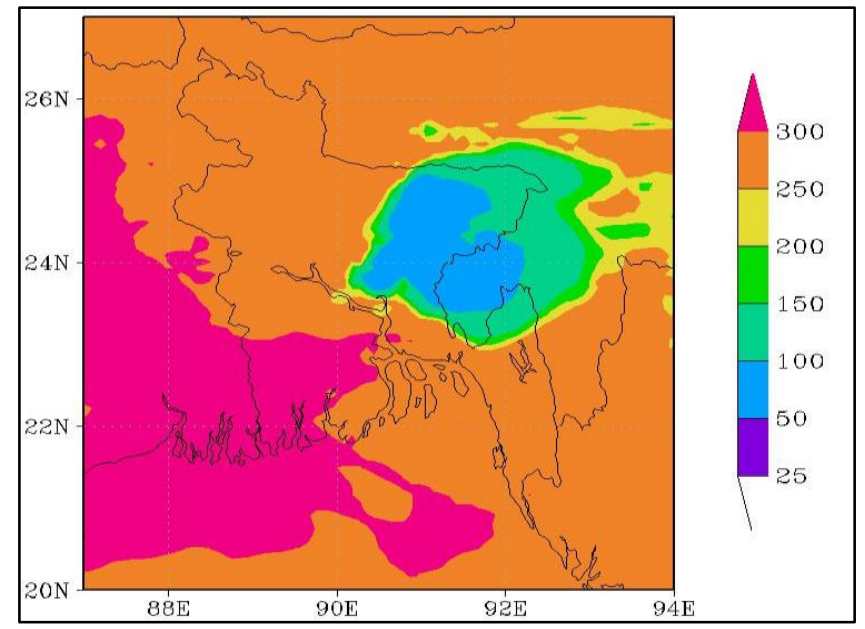

Fig. 10. Spatial pattern of OLR visualized at 1000 UTC of 30 March 2018.

The spatial pattern of a derived parameter namely Outgoing Longwave Radiation (OLR) has been depicted in Fig.10. for 1000 UTC of 30 March 2018. This derived parameter measures the outgoing terrestrial radiation released by earth surface. Water vapor suspending in the atmosphere is the best absorber of this longwave radiation. Cloud cover also prevent this radiation from escaping to the outer space from the earth. Denser the cloud, the lower is the OLR. A much lower value $\left(\sim 50-100 \mathrm{Wm}^{-2}\right)$ of OLR has been identified over the northeast Bangladesh and the areas adjacent to it. From this fact, it is advisable that dense cumulonimbus cloud formed by vigorous convection exists over those regions.

\section{Convective Available Potential Energy (CAPE) and Convective Inhibition Energy (CINE)}

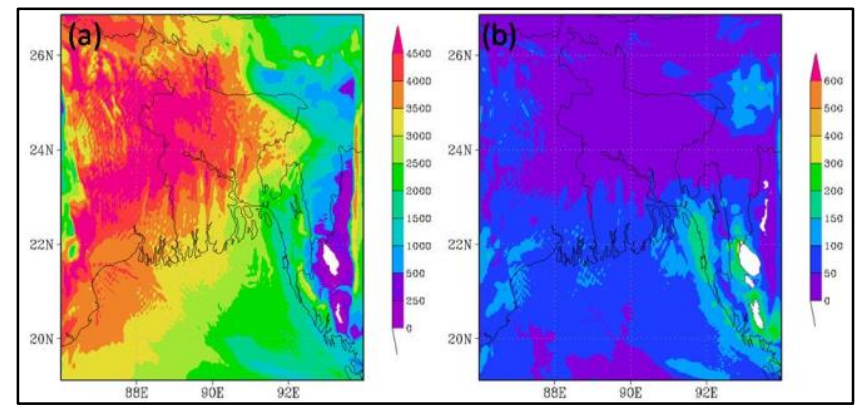

Fig. 11. CAPE and CINE distributed over Bangladesh and nearby areas at 1000 UTC of 30 March 2018.

Two instability indices of the atmosphere specified by CAPE and CINE which are the measure of convection have been represented in Fig.11. (a) and (b) respectively for the time 1000 UTC of 30 March 2018. A tongue of high values of CAPE $\left(\sim 3000-4500 \mathrm{JKg}^{-1}\right)$ persists over northern (intense over northeast region) Bangladesh and adjoining West Bengal and Bihar in India (Fig.11. (a)). Besides, low values $\left(\sim 0-50 \mathrm{JKg}^{-1}\right)$ of CINE are prevalent over the same regions (Fig.11. (b)). Both high values of CAPE and low CINE values are the signature of the possibility of free convection over that particular region. By merging these two findings we can conclude that it is possible to initiate vigorous convection thermodynamically over those regions.

\section{Rainfall Analysis}

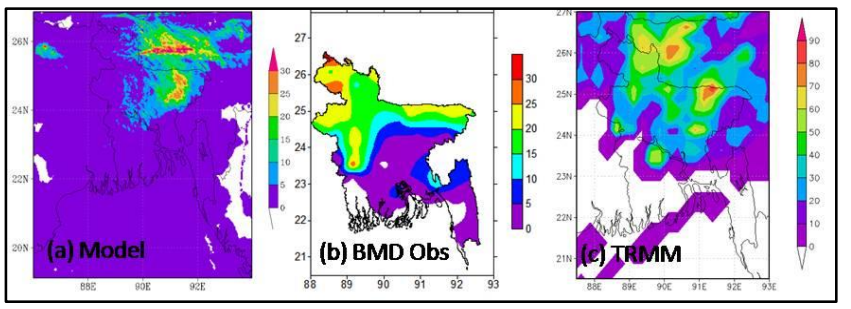

Fig. 12. Total daily (a) model simulated, (b) BMD observatory recorded and (c) TRMM estimated rainfall at the time 0000 UTC of 30 March 2018.

Fig.12. (a-c) distinguishes the daily (total of 24 hours) rainfall simulated by model with the station rainfall data recorded by BMD and TRMM 3B42 V7 estimated rainfall valid at 0000 UTC of 31 March 2018. We found fairly good similarity and consistency in both spatially and temporally between these three sets of data. Nevertheless, rainfall simulated by the model presents lower values than BMD recorded and TRMM estimated rainfall. The location of higher values of rainfall was also confined to a narrower space. The slight dissimilarity between model simulated and BMD recorded rainfall can be accounted by the fact 
that stations of BMD are very sparse (very few over northeast Bangladesh) throughout the country and are not sufficient yet to meet the increasing needs for accurate prediction of thunderstorm which is an immensely localized atmospheric phenomenon. It is suggested that the dissimilarity might be reduced by regrinding every data to having the same values of resolution. This would be accomplished in our future research of thunderstorm by simulating through NWP models.

\section{Conclusion}

The thunderstorm which occurred on 30 March 2018 has been simulated using WRF model with double nested domain with resolution of $9 \mathrm{~km}$ in the outer domain and 3 $\mathrm{km}$ in the inner domain. The model has been initialized by using gridded dataset of 0000 UTC. The simulated pressure distribution at 1000 UTC shows large scale low pressure trough with strong convergence of winds over the northeastern Bangladesh and adjacent areas of India. The simulated field show high concentration of moisture in the northwestern Bangladesh, which is brought to inland by strong southerly wind. The analysis shows high values of CAPE (4000-5000J/kg). The model simulation shows strong vertical wind shear between 500 and $950 \mathrm{mb}$ levels, which favours the thunderstorm formation with strong updraft of moist air. Very interesting feature is demonstrated by the vorticity fields, which are arranged in northwest to southeast oriented stripes with alternating positive and negative vorticity signifying ascending and descending motion within the convective cells. The simulated rainfall shows lower values compared to BMD data and TRMM rainfall distribution and demonstrates good matching. The simulated OLR shows low OLR over the northeastern Bangladesh. The results of the modelling exercise demonstrates that the WRF model has successfully captured the synoptic and thermodynamic features related to thunderstorm development.

\section{References:}

1. Prasad K., 2006. Environment and synoptic conditions associated with Nor'westers and Tornadoes in Bangladesh: An appraisal based on Numerical Weather Prection (NWP) guidance products, SAARC Meteorlogical Research Centre, Scientific Report.

2. Saha T. R. and D. A. Quadir, 2016. Variabilty and trends of annual and seasonal thunderstorm frequency over Bangladesh. International Journal of Climatology, 36(14), 4651-4666.

3. Karmakar S., 2001. Climatology of thunderstorm days over Bangladesh during the pre-monsoon season. Bangladesh Journal of Science and Technology, 3(1), 103-122.

4. Das S., 2010. Climatology of Thunderstorms over the $S A A R C$, SAARC Meteorological Research Center (SMRC), Scientific Report.

5. Akter N. and M. N. Islam, 2007. Use of MM5 model for weather forecasting over Bangladesh region. BRAC University Journal, 4(1), 75-79.
6. Akter N. and M. N. Islam, 2009. Employment of MM5 in simulation MCSs developed in and around Bangladesh. MAUSAM, 60(2), 137-146.

7. Ahasan M. N., M. N. Islam and N. Ferdousi, 2010. Dhaka, Bangladesh, Proceedings of the SAARC Seminar on Nor'westers and Tornadoes over the SAARC Region and their Forecasting \& Preparedness, 143-146.

8. Ahasan M. N., D. A. Quadir, K. A. Khan and M. S. Haque, 2014.Simulation of a thunderstorm event over Bangladesh using WRF-ARW model, Journal of Mechanical Engineering, Institute of Engineers Bangladesh (IEB), 44(2), 124-131.

9. Das S., M. K. Das, A. Sarkar and M. M. Rahman, 2015. Composite characteristics of Nor'westers based on observations and simulations. Atmospheric Research, 158, 158-178.

10. SAARC-STORM, 2011. SAARC STORM Pilot Field Experiment 2010, SAARC Meteorological Research Centre (SMRC), Scientific Report.

11. SAARC-STORM, 2013. SAARC STORM Pilot Field Experiment 2011, SAARC Meteorological Research Center (SMRC), Scientific Report.

12. Skamarock W. C., J. B. Klemp, J. Dudhia, D. O. Gill, D. M. Barker, M. G. Duda, X.-Y. Huang, W. Wang and J. G. Powers, 2008. A Description of the Advanced Research WRF Version 3. Boulder, Colorado: Mesoscale and Microscale Meteorology Division, National Center for Atmospheric research.

13. Kain J. S., 2004. The Kain-Fritsch Convective Parameterization: An Update. Journal of Applied Meterology, 43, 170-181.

14. Hong S.-Y. and J.-O. J. Lim, 2006. The WRF Single-Moment 6-Class Microphysics Scheme (WSM6). Journal of the Korean Meteorological Society, 42(2), 129-151.

15. Mlawer E. J., S. J. Taubman, P. D. Brown, M. J. Iacono and S. A. Clough 1997. Radiative transfer for inhomogeneous atmospheres: RRTM, a validated correlated-k model for the long wave. Journal of Geophysical Research, 102(D14), 16663-16682.

16. Dudhia J., 1989. Numerical study of convection observed during the Winter Monsoon Experiment using a mesoscale two dimensional model. Journal of Atmospheric Sciences, 46(20), 3077-3107.

17. Hong S.-Y., Y. Noh and J. Dudhia, 2006. A new vertical diffusion package with and explicit treatment of entrainment process. Monthly Weather Review, 134, 2318-2341.

18. Holton J. R., 2004. An Introduction to Dynamic Meteorology, Fourth Edition, International Geophysics Series, 88, Chapter 9, 296-313. 
